\title{
Kajian Bahasa Pragmatik pada Tari Endah Karya S. Maridi
}

\author{
Maryono \\ Institut Seni Indonesia (ISI) Surakarta \\ Jl. Ki Hajar Dewantara No. 19 Kentingan, Jebres, Surakarta 57126
}

\begin{abstract}
This research aims to uncover the meaning of Tari Endah from a pragmatic linguistic perspective. The approach to the study uses a qualitative descriptive method. The theoretical foundation refers mainly to pragmatic theories and performing art theories. The application of pragmatic theories is used to research the verbal components while performing arts theories are applied to study the nonverbal components.

Based on an analysis of the verbal and nonverbal components of Tari Endah, it was concluded that this dance is a romantic couples dance which is hoped to act as a good example for newlywed couples and the community in general. In addition, Tari Endah is a form of aesthetical entertainment which is highly beneficial for the audience in fulfilling their spiritual and physical needs.
\end{abstract}

Keywords: pragmatic language, verbal components, and nonverbal components

\begin{abstract}
ABSTRAK
Penelitian ini bertujuan untuk mengungkap makna Tari Endah ${ }^{1}$ dari perspektif linguistik pragmatik. Pendekatan penelitiannya menggunakan metode kualitatif deskriptif. Landasan teoritis yang dirujuk lebih mengacu pada teori pragmatik dan teori seni pertunjukan. Bentuk aplikasinya, teori pragmatik digunakan untuk menggali komponen yang bersifat verbal, sedangkan teori seni pertunjukan untuk mengkaji komponen yang bersifat nonverbal.

Berdasarkan analisis komponen verbal dan nonverbal pada Tari Endah didapat suatu simpulan bahwa Tari Endah merupakan salah satu bentuk tari pasangan percintaan yang diharapkan dapat dicontoh dan diteladani bagi sepasang pengantin dan masyarakat penonton pada umumnya. Di samping itu Tari Endah juga merupakan bentuk hiburan estetik yang sangat bermanfaat untuk pemenuhan kebutuhan rohani dan jasmani dalam berbagai aktivitas kehidupan manusia.
\end{abstract}

Kata kunci: bahasa pragmatik, komponen verbal, dan komponen nonverbal

\section{PENDAHULUAN}

Bahasa pragmatik merupakan cabang ilmu linguistik yang dapat dikategorikan disiplin ilmu baru. Pentingnya pragmatik dalam kehidupan adalah adanya kesadaran bahwa untuk mengungkap hakikat makna bahasa tidak akan mendapatkan hasil maksimal seperti yang diharapkan tanpa dilandasi pemahaman terhadap pragmatik, yaitu bagaimana bahasa itu diguna- 
kan dalam berkomunikasi (Leech, 1983:1). Sebagai subdisiplin linguistik, pragmatik mengaitkan bahasa sebagai sistem lambang dengan pemakai bahasa. Oleh karena itu pragmatik tidak hanya dari sebuah disiplin sempit yang mengurusi data fisik bahasa, namun menjadi suatu disiplin yang luas yang mencakup: bentuk, makna, dan konteks (Leech, 1993:2).

Bahasa secara garis besar dapat dibagi menjadi dua, yaitu: bahasa formal atau struktural dan bahasa pragmatik. Bahasa formal adalah ilmu bahasa yang mengkaji kaidah-kaidah bahasa secara internal yang mencakup: fonologi, morfologi, sintaksis, semantik, dan wacana. Pragmatik adalah disiplin ilmu bahasa yang mempelajari makna satuan-satuan kebahasaan secara eksternal. Satuan-satuan kebahasaan dalam pragmatik tidak diamati secara internal, tetapi dilihat dari bagaimana bahasa itu dikomunikasikan. Hal itu sejalan dengan pernyataan Parker: "Pragmatic is the study of how language is used to communicate. Pragmatic is distinct from grammar, which is the study of the internal structure of language" (1986:11 lihat Wijana, 1995). Rupanya semakin tampak bahwa pragmatik pada dasarnya berkaitan dengan fungsi bahasa, yakni bagaimana bahasa itu digunakan atau difungsikan oleh penutur atau pemakai bahasa dalam kondisi interaksi atau komunikasi.

Ilmu pragmatik merupakan salah satu subdisiplin linguistik yang sangat bermanfaat untuk mengkaji ungkapan-ungkapan yang bersifat verbal dan nonverbal. Dasar pemahamannya bahwa sasaran kajiannya terhadap objek-objek yang secara substantif memiliki komponen verbal dan komponen nonverbal yang terintegratif. Dengan demikian seni pertunjukan merupakan sasaran yang sangat tepat dan potensial sebagai lahan kajian pragmatik, mengingat dapat dipastikan di dalamnya terkandung komponen verbal dan komponen nonver- bal yang komplementer. Komponen verbal merupakan ungkapan yang bersifat kebahasaan yang berupa kata-kata atau kalimat. Sedangkan komponen nonverbal adalah ungkapan pengalaman jiwa yang diekspresikan melalui: gerak, rias, busana, musik, dan lainnya (lihat Maryono, 2010). Adapun jenis-jenis seni yang termasuk dalam seni pertunjukan, di antaranya: seni tari, karawitan, pedalangan, kethoprak, wayang orang, langendriyan, dan lainnya.

Tari Endah merupakan salah satu tari duet atau pasangan silang jenis yang menggambarkan percintaan Damarwulan dengan Dewi Anjasmara. Karya Tari Endah merupakan susunan S. Maridi yang memiliki gelar keempuannya di bidang tari dengan sebutan Kanjeng Raden Tumenggung Tanda Kusuma (Hartoyo, wawancara 2013). Secara substansi Tari Endah mengandung komponen verbal dan komponen nonverbal yang komplementer sehingga teraktualisasi dalam bentuk pertunjukan tari yang utuh. Komponen verbal Tari Endah berupa teks gérongan, sedangkan komponen nonverbalnya terdiri dari tema, gerak, rias, busana, dan musik.

Dalam rangka mengkaji bahasa pragmatik pada Tari Endah, digunakan landasan teori pragmatik dan teori seni pertunjukan. Teori pragmatik untuk menganalisis jenisjenis tindak tutur, konteks, dan implikatur komponen yang bersifat verbal atau bentuk kebahasaan, sedangkan teori seni pertunjukan digunakan untuk mengkaji komponen yang bersifat nonverbal pada Tari Endah.

\section{PEMBAHASAN}

\section{Bentuk Tari Endah}

Tari Endah adalah salah satu bentuk tari pasangan yang bertemakan percintaan yang disusun pada tahun 1971 (Maryono, 1991: 118). Nama Tari Endah merujuk pada kata 
Endah yang terdapat pada cakepan 'syair teks' gérongan Ladrang Énggar-énggar yang berbunyi: Éndahé sinawang anengsemaké. Ide garapnya bahwa Tari Endah dimaknai sebagai bentuk pertunjukan tari yang indah, mempesona, dan memikat terhadap orang banyak (Hartoyo, wawancara 2013). Bentuk pertunjukannya disajikan secara duet dengan silang karakter, yaitu putri lanyap untuk tokoh Dewi Anjasmara dan putra luruh untuk peran Damarwulan. Menurut Ninik Sutranggi, bentuk koreografinya dapat dibagi menjadi empat adegan, yaitu penantian, pertemuan, kegembiraan, dan kebahagiaan (Ibid, 2013: wawancara). Masing-masing adegan ditandai dengan adanya perubahan suasana-suasana yang dapat dicermati dari komponen yang bersifat verbal maupun nonverbal.

Kehadiran Tari Endah dalam masyarakat lebih banyak difungsikan dalam rangkaian ritual perkawinan adat Jawa. Menurut Daryono, setelah dapat mempopulerkan karyanya tari percintaan Karonsih, rupanya S. Maridi menghendaki adanya alternatif baru, yaitu Tari Endah (2013: wawancara). Bentuk alternatif yang ditawarkan pada Tari Endah adalah busana dodotan untuk peran putri dan blangkonan untuk peran putra. Desain busana Tari Endah yang menyerupai pasangan pengantin Jawa rupanya semakin mendapatkan apresiasi positif masyarakat. Tari Endah digunakan dalam ritual perkawinan adat budaya Jawa. Selain itu bentuk perkembangan Tari Endah juga didukung dengan rekaman musiknya dalam bentuk kaset sehingga memperlancar dan memudahkan dalam pelaksanaan pertunjukannya (Hartoyo, wawancara 2013).

\section{Komponen Verbal Tari Endah}

Bentuk komponen verbal pada Tari Endah diwujudkan dari unsur-unsur kebahasaan yang tercermin pada sastra tem- bangnya. Merujuk pada fungsinya, sastra tembang yang terdapat pada Tari Endah bisa diklasifikasikan menjadi dua, yaitu sebagai sarana ekspresi penari dalam rangka berkomunikasi secara langsung dan sebagai media untuk menggambarkan suasana peristiwa yang tengah terjadi pada adegan tersebut. Secara keseluruhan komponen verbal yang terdapat pada Tari Endah berbentuk teks gérongan: Ayak-ayakan Mangu, Ladrang Énggar-énggar, dan Lancaran Makarya.

Secara keseluruhan komponen verbal Tari Endah terdiri dari tiga teks gérongan. Masing-masing teks gérongan dikaji jenisjenis tindak tutur, konteks, dan implikasi atau makna yang tersirat dalam teks. Tindak tutur dapat dikategorisasikan menjadi tujuh, yaitu: ekspresif, direktif, asertif, performatif, verdiktif, komisif, dan patik (Kreidler, 1998:183-194). Mengacu pada teori tindak tutur yang dinyatakan Kreidler, maka komponen verbal yang terdapat dalam Tari Endah dapat dianalisis sebagai berikut.

Teks gérongan Ayak-ayakan Mangu laras pélog pathet nem

Damarwulan: Dhuh yayi apuranta/Pun kakang nuju karsa/Datanpa ginggang sarikma/Mirah ambalAyo sami tilamsari. (Video Tari Endah, koleksi STSI Solo).

[Damarwulan: Aduh adinda mohon dimaafkan/Kakanda memahami kehendak adinda/Tidak akan berpisah sekalipun hanya sehelai rambut/Kekasih hatiku/Mari kita bersama-sama tidur.]

\section{Konteks}

Peserta tutur: Damarwulan (Penutur/Pn) dan Dewi Anjasmara (Petutur/Pt). Tema: percintaan. Tujuan: bentuk ungkapan permintaan maaf dari Damarwulan terhadap istrinya Dewi Anjasmara. Status sosial: Damarwulan merupakan seorang prajurit yang dinobatkan sebagai senopati dari Kerajaan Majapahit. Dewi Anjasmara 


\begin{tabular}{|c|c|c|c|c|}
\hline No & Tokoh & $\begin{array}{c}\text { Teks Verbal gérongan Ayak-ayakan } \\
\text { Mangu laras pélog pathet nem }\end{array}$ & Jenis-jenis TT & Pemarkah \\
\hline 1 & Damarwulan & Dhuh yayi apuranta, & Direktif & apuranta \\
2 & Damarwulan & Pun kakang nuju karsa, & Direktif & nuju karsa \\
3 & Damarwulan & Datanpa ginggang sarikma, & Direktif & datanpa \\
4 & Damarwulan & Mirah amba, & Ekspresif & mirah \\
5 & Damarwulan & Ayo sami tilamsari. & Direktif & ayo \\
\hline
\end{tabular}

Tabel 1

Jenis - jenis Tindak Tutur (TT) yang melekat pada Teks gérongan Ayak-ayakan Mangu laras pélog pathet nem dan Pemarkah.

merupakan putri dari seorang Mahapatih Logender dari Majapahit. Damarwulan digambarkan sebagai seorang suami yang memiliki rasa tanggungjawab, romantis, dan setia terhadap istri, sedangkan Dewi Anjasmara digambarkan sebagai figur seorang istri yang setia, romantis, dan berbakti terhadap suami. Tempat: di dalam lingkungan Kepatihan Majapahit. Situasi tutur: tidak formal.

Dalam analisis implikatur, Levinson berpendapat implikatur percakapan adalah, "the notion of conversational implicature is one of the single most important ideas in pragmatics" (1983:97). Secara ringkas implikatur dapat dinyatakan sebagai sebuah makna yang disiratkan dalam sebuah percakapan. Adapun implikatur tembang gérongan Ayak-ayakan Mangu adalah bentuk ungkapan minta maaf dari Damarwulan terhadap Dewi Anjasmara istrinya dan sekaligus berjanji untuk mencitainya dengan setia.

Teks gérongan Ladrang Énggar-énggar laras pélog pathet barang

Damarwulan: Éndahé sinawang anengsemakélKembangé sumerbak arum gandanél Taluki menur mlathinélKatiyubing maruta angawé-awé/Dhuhlahé iba yèn dicundhuakél Pantesé sumelip anèng gelungél Dhasar bisa matrapakélJumbuhklawan alus luhuring budiné(Video Tari Endah, koleksi STSI Solo).

[Damarwulan: Indahnya jika dilihat menakjubkan/Bunganya harum mewangi/Bunga taluki, menur, dan melati/Ter- tiup angin melambai-lambai/Alangkah indahnya jika disisipkan/Bagusnya disisipkan pada kondenya/Memang bisa memasang dengan baik/Sesuai dengan kehalusan budi pekertinya].

\section{Konteks}

Peserta tutur: Damarwulan (Penutur) dan Dewi Anjasmara (Petutur). Tema: percintaan. Tujuan: suatu ungkapan dari Damarwulan yang selalu menyanjung, terhadap istrinya Dewi Anjasmara. Status sosial: Damarwulan digambarkan suami yang bertanggungjawab, romantis, dan setia. Dewi Anjasmara digambarkan seorang istri yang setia, romantis, dan berbakti. Tempat: di dalam lingkungan kepatihan Majapahit. Situasi tutur: tidak formal.

Implikatur tembang gérongan Ladrang Énggar-énggar adalah bentuk ungkapan cinta kasih, kesetiaan yang mendalam Damarwulan terhadap Dewi Anjasmara istrinya.

Teks gérongan Lancaran Makarya laras pélog pathet barang

Damarwulan: Ayo yayi yo bareng makarya/Yo ayo dhatumandang yo yo bareng tumandang/Kasuka kasuka ngayahi karyaning praja/Kanggo nusa bangsa mulya salamiya (Video Tari Endah, koleksi STSI Solo).

[Damarwulan: Mari adinda bekerja bersama-sama/ Marilah kita segera laksanakan/ mari bersama-sama melak- 


\begin{tabular}{|c|c|c|c|c|}
\hline No & Tokoh & $\begin{array}{l}\text { Teks Verbal gérongan Ladrang Énggar- } \\
\text { énggar laras pélog pathet barang }\end{array}$ & Jenis-jenis TT & Pemarkah \\
\hline 1 & Damarwulan & Éndahé sinawang anengsemaké, & Ekspresif & éndahé \\
\hline 2 & Damarwulan & Kembangé sumerbak arum gandané, & Ekspresif & sumerbak arum \\
\hline 3 & Damarwulan & $\begin{array}{c}\text { Taluki menur mlathiné, Katiyubing } \\
\text { maruta angawé-awé, }\end{array}$ & Ekspresif & $\begin{array}{l}\text { katiyubing } \\
\text { maruta }\end{array}$ \\
\hline 4 & Damarwulan & Dhuhlahé iba yèn dicundhuaké, & Direktif & dicundhuaké \\
\hline 5 & Damarwulan & Pantesé sumelip anèng gelungé, & Direktif & pantesé \\
\hline 6 & Damarwulan & $\begin{array}{c}\text { Dhasar bisa matrapaké, Jumbuh klawan } \\
\text { alus luhuring budiné, }\end{array}$ & Ekspresif & $\begin{array}{l}\text { luhuring } \\
\text { budiné }\end{array}$ \\
\hline 7 & Damarwulan & Éndahé sinawang anengsemaké, & Ekspresif & éndahé \\
\hline 8 & Damarwulan & Kembangé sumerbak arum gandané, & Ekspresif & $\begin{array}{l}\text { sumerbak } \\
\text { arum }\end{array}$ \\
\hline 9 & Damarwulan & $\begin{array}{c}\text { Taluki menur mlathiné, Katiyubing } \\
\text { maruta angawé-awé, }\end{array}$ & Ekspresif & $\begin{array}{l}\text { katiyubing } \\
\text { maruta }\end{array}$ \\
\hline 10 & Damarwulan & Dhuhlahé iba yèn dicundhuaké, & Direktif & dicundhuaké \\
\hline 11 & Damarwulan & Pantesé sumelip anèng gelungé, & Direktif & pantesé \\
\hline 12 & Damarwulan & $\begin{array}{c}\text { luhuring budiné,Dhasar bisa matrapaké, } \\
\text { Jumbuh klawan alus }\end{array}$ & Ekspresif & $\begin{array}{l}\text { luhuring } \\
\text { budiné }\end{array}$ \\
\hline
\end{tabular}

Tabel 2

Jenis-jenis Tindak Tutur (TT) yang melekat pada Teks gérongan Ladrang Énggar-énggar laras pélog pathet barang dan Pemarkah

sanakan/ Dengan senang melakukan pekerjaan Negara/ Untuk kemuliaan, kesejahteraan nusa dan bangsa selamalamanya.]

\section{Konteks}

Peserta tutur Damarwulan (Penutur) dan Dewi Anjasmara (Petutur). Tema: percintaan. Tujuan: Damarwulan mengajak istrinya Dewi Anjasmara untuk bersama-sama melakukan pekerjaan dengan hati tulus, gembira untuk kesejahteraan dan kebahagiaan selamanya. Status sosial: Damarwulan digambarkan suami yang bertanggungjawab, romantis, dan setia. Dewi Anjasmara sebagai figur istri yang setia, romantis, dan berbakti. Tempat: di luar kepatihan Majapahit. Situasi tutur: tidak formal.
Implikatur tembang gérongan Lancaran Makarya laras pélog pathet barang adalah penggambaran kebahagiaan Damarwulan dan istrinya Dewi Anjasmara dalam kebersamaannya membina rumahtangga.

\section{Komponen Nonverbal Tari Endah}

Komponen nonverbal adalah unsurunsur atau elemen-elemen yang bentuknya bersifat nonkebahasaan (Maryono, 2012: 42). Bentuk dan wujudnya secara umum dapat berupa simbol, isyarat, kode, dan bunyi-bunyian, misalnya: tanda lalu lintas, morse, lambaian tangan, sirene, kenthongan; lambang tersebut baru bermakna setelah diterjemahkan ke dalam bahasa manusia (Lamuddin Finoza, 2005:2). Dalam pertunjukan Tari Endah, komponen yang bersifat nonverbal merupakan elemen-elemen fisik 


\begin{tabular}{|c|c|c|c|c|}
\hline No & Tokoh & $\begin{array}{l}\text { Teks Verbal gérongan Lancaran } \\
\text { Makarya laras pélog pathet barang }\end{array}$ & Jenis-jenis TT & Pemarkah \\
\hline 1 & Damarwulan & Ayo yayi yo bareng makarya, & Direktif & ayo \\
\hline 2 & Damarwulan & $\begin{array}{c}\text { Yo ayo dhatumandang yo yo bareng } \\
\text { tumandang, }\end{array}$ & Direktif & yoayo \\
\hline 3 & Damarwulan & $\begin{array}{l}\text { Kasuka kasuka ngayahi } \\
\text { karyangning praja, }\end{array}$ & Direktif & ngayahi \\
\hline 4 & Damarwulan & $\begin{array}{c}\text { Kanggo nusa bangsa mulya } \\
\text { salamiya }\end{array}$ & Direktif & $\begin{array}{l}\text { mulya } \\
\text { salamiya }\end{array}$ \\
\hline 5 & Damarwulan & Ayo yayi yo bareng makarya, & Direktif & ayo \\
\hline 6 & Damarwulan & $\begin{array}{c}\text { Yo ayo dhatumandang yo yo } \\
\text { bareng tumandang, }\end{array}$ & Direktif & yоауо \\
\hline 7 & Damarwulan & $\begin{array}{l}\text { Kasuka kasuka ngayahi } \\
\text { karyangning praja, }\end{array}$ & Direktif & ngayahi \\
\hline 8 & Damarwulan & $\begin{array}{c}\text { Kanggo nusa bangsa mulya } \\
\text { salamiya }\end{array}$ & Direktif & $\begin{array}{l}\text { mulya } \\
\text { salamiya }\end{array}$ \\
\hline
\end{tabular}

Tabel 3

Jenis-jenis Tindak Tutur (TT) yang melekat pada Teks gérongan Lancaran Makarya laras pélog pathet barang dan Pemarkah

yang secara visual dapat dilihat, didengar, dinikmati, dan dihayati dengan indera manusia. Adapun bentuk dan wujudnya, antara lain adalah: tema, gerak tubuh, rias, busana, dan musik. Kehadiran elemen-elemen pada komponen nonverbal Tari Endah bersifat tidak parsial dan bukan merupakan penggabungan, namun lebih merupakan persenyawaan yang menyatu dan utuh.

\section{Tema}

Tema dapat ditarik dari sebuah peristiwa atau cerita, yang selanjutnya dijabarkan menjadi alur cerita sebagai kerangka sebuah garapan (Maryono, 2010: 53). Bentuk tema Tari Endah adalah percintaan yang bertolak dari sumber wiracarita Langendriya Mandraswara (lihat Sutarno Haryono, 2010: 203). Tema percintaan yang diaktualisasikan pada Tari Endah merupakan penggambaran percintaan antara Damarwulan dengan Dewi Anjasmara. Dikisahkan Damarwulan adalah salah satu prajurit yang sakti dari Kerajaan Majapahit. Ketika
Majapahit diserang Adipati Menakjingga beserta balatentaranya dari Blambangan banyak senopatinya yang gugur di medan laga. Damarwulan diangkat senopati dan mendapat tugas untuk menumpas Adipati Menakjingga. Sebelum berangkat Damarwulan minta ijin kepada istrinya, yaitu Dewi Anjasmara di Kepatihan. Sebagai pasangan suami-istri yang lama tidak berjumpa, Damarwulan dan Anjasmara saling melepas kerinduan, bercinta, dan bermesraan. Rupanya episode percintaan Damarwulan dan Anjasmara di Kepatihan ini pada akhirnya diangkat sebagai tema Tari Endah (Hartoyo, wawancara 2013).

Tari Endah yang disusun oleh S. Maridi Tanda Kusuma seorang empu tari tradisi gaya Surakarta pada tahun 1971, sesungguhnya merupakan sempalan dari Dramatari Bangun Majapahit karya S. Maridi yang pentas perdananya dilakukan untuk Festival Jawa Tengah di Semarang. Menurut Ninik Sutranggi sebagai penari pemeran Dewi Anjasmara, susunan Tari Endah dapat dibagi menjadi empat adegan, yaitu adegan penantian, pertemuan, kegembiraan, dan kebahagiaan (wawancara 2013). 


\begin{tabular}{|c|l|c|c|c|c|}
\hline No & Jenis TT & $\begin{array}{c}\text { Teks gérongan } \\
\text { Ayak-ayakan } \\
\text { Mangu }\end{array}$ & $\begin{array}{c}\text { Teks gérongan } \\
\text { Ladrang Énggar- } \\
\text { énggar }\end{array}$ & $\begin{array}{c}\text { Teks gérongan } \\
\text { Lancaran } \\
\text { Makarya }\end{array}$ & Jumlah \\
\hline 1 & Direktif & 4 & 4 & 8 & 16 \\
2 & Ekspresif & 1 & 8 & - & 9 \\
3 & Asertif & - & - & - & - \\
4 & Verdiktif & - & - & - & - \\
5 & Komisif & - & - & - & - \\
6 & Patik & - & - & - & - \\
7 & Performatif & - & Jumlah total & & - \\
8 & & \multicolumn{4}{c}{}
\end{tabular}

Tabel 4

Rekapitulasi jenis-jenis TT pada komponen verbal Tari Endah

\section{Gerak}

Menurut Soedarsono, secara garis besar jenis tarian representasional dan nonrepresentasional dalam garap geraknya terkandung adanya dua jenis gerak, yaitu maknawi dan murni (1978: 22). Hal itu sejalan dengan pernyataan Maryono, bahwa gerak dalam garapan tari dapat diklasifikasikan menjadi dua jenis, yaitu gerak presentatif dan gerak representatif (lihat Maryono, 2010: 56). Dalam Tari Endah, gerak representatif mendominasi karena untuk menggambarkan percintaan Anjasmara dan Damarwulan.

Ragam gerak pada adegan I (penantian), Dewi Anjasmara dari pojok belakang srisik sampir sampur tangan kiri memutar mengitari panggung satu lingkaran, lalu menuju tengah. Suasana adegan gelisah, sedih, dan ragu-ragu yang dialami Dewi Anjasmara dalam menanti kedatangan Damarwulan. Ragam gerak yang mendukung suasana tersebut, antara lain srisik, sekaran sindhet, lumaksana lémbéhan kebyokan sampur dengan ngglébag kanan-kiri, dan srisik tangan kiri miwir sampur.

Ragam gerak pada adegan II (pertemuan), Damarwulan srisik kebyok sampur kanan kedua tangan nekuk dari pojok menuju tengah dan bertemu Dewi Anjasmara. Damarwulan tanjak nikelwarti, pang- gel, menthang kedua tangan sambil ingsetan, sedangkan Anjasmara menghaturkan sembah bekti dengan gerak sindhet kebyok sampur kiri, jèngkèng, dan sembahan laras. Rasa trenyuh, haru Damarwulan pelan-pelan jèngkèng, sangganampa disambut Anjasmara dengan nampa asta. Suasana akrab dan romantis diungkapkan dengan gerak sindhet, laku miring ogèkan seblak sampur kanan.

Ragam gerak pada adegan III (gembira), Anjasmara tersipu malu merenggang dengan kèngser begitu pula Damarwulan. Kedua tokoh melakukan gerak bersama sekaran sindhet sambil mendekat, lémbéhan usap gulu dan sindhet. Suasana gembira diekspresikan dengan sekaran batangan dan laku lémbéhan ukel karna. Anjasmara srisik ke pojok diikuti Damarwulan lalu nyandhet mundur. Damarwulan dengan gerak lilingan ingsetan ulap-ulap tawing kanan-kiri, sedangkan Anjasmara menggoda Damarwulan dengan ukel karna seblakan sambil berputar. Anjasmara dan Damarwulan gerak bersama sindhet, laku telu, srisik memutar sambil berpegangan tangan, lalu sindhet dan jèngkèng.

Suasana gembira dan romantis semakin meningkat yang diawali Damarwulan berdiri mendekati istrinya, Anjasmara, yang juga maju mendekat dengan gerak laku 


\begin{tabular}{|c|ccc|}
\hline No & \multicolumn{2}{|c|}{$\begin{array}{c}\text { Jenis-jenis TT } \\
\text { pada komponen verbal } \\
\text { Tari Endah }\end{array}$} & Jumlah \\
\hline 1 & Direktif & $16: 25 \times 100$ & $64 \%$ \\
2 & Ekspresif & $9: 25 \times 100$ & $36 \%$ \\
3 & Asertif & - & - \\
4 & Verdiktif & - & - \\
5 & Komisif & - & - \\
6 & Patik & - & - \\
7 & Performatif & - & - \\
8 & Jumlah total & $100 \%$ \\
\hline
\end{tabular}

Tabel 5

Persentase jenis-jenis TT pada komponen verbal Tari Endah

kebyok sampur. Suasana kemesraan ditunjukkan oleh Damarwulan dan Anjasmara dengan posisi berdekatan dan melakukan gerak bersama laku entrakan, srisik sambil berpegangan tangan. Keceriaan semakin tampak setelah Anjasmara sindhet berhadapan dengan Damarwulan kemudian keduanya laku ogékan mandhé sampur sambil melingkar, srisik saling mendekat.

Ragam gerak pada adegan IV (bahagia), Damarwulan lumaksana nayung, Anjasmara posisi di depannya lumaksana penthangan. Suasana gembira, riang, dan bahagia diekspresikan dengan gerak yang dinamis, lincah, dan sigrak yang diawali Damarwulan dengan gerak lilingan seblakan penthangan ingsetan, sedangkan Anjasmara menggunakan gerak ngoré rikma kanan-kiri. Selanjutnya keduanya laku miring penthangan, tawing kiri sambil memutar, srisik saling mendekat, dan laku miring berpegangan tangan. Akhir dari adegan bahagia ini, Damarwulan dan Dewi Anjasmara srisik penthangan sampur kiri dengan berpegangan tangan kanan.

\section{Rias}

Dalam sebuah pertunjukan rias memegang peranan penting, mengingat rias memberikan kontribusi dalam mewujud- kan karakter yang diinginkan koreografer. Menurut Maryono, secara umum bentuk rias dapat diklasifikasikan menjadi tiga jenis, yaitu: (1) rias formal, (2) rias informal, dan (3) rias peran (2010:58). Mengacu ketiga jenis rias tersebut, rupanya rias peran merupakan jenis rias yang digunakan dalam Tari Endah. Rias peran merupakan jenis rias yang mampu mengubah wajah pribadi menjadi wajah karakter peran supaya dapat tampil ekspresif.

Bentuk rias Tari Endah untuk tokoh Dewi Anjasmara menggunakan rias peran cantik yang berkarakter lanyap seperti tokoh Srikandi. Garis-garis untuk sifatan alis, mata, dan sinom rambut lebih tajam sehingga peran karakter lanyapnya tampak dan mantap. Riasan Damarwulan adalah rias bagusan luruh yang secara visual dapat menunjukkan karakteristik kalem, tenang, dan bersifat introvert. Garis-garis untuk sifatan alis, mata, dan sinom rambut tidak tebal dan tidak tajam sehingga tampak sederhana dan kalem.

\section{Busana}

Desain busana yang dipakai kedua tokoh pada Dramatari Bangun Majapahit, semula menggunakan pakaian panjen untuk Damarwulan dan Dewi Anjasmara memakai pakaian semacam tokoh Mustakaweni dalam wayang orang. Setelah disusun dalam bentuk Tari Endah, Damarwulan memakai busana blangkonan sedangkan Dewi Anjasmara memakai dodot tanggung layaknya busana pengantin putri gaya Karaton Surakarta. Menurut Hartoyo perubahan busana ini dilatarbelakangi dari pemikiran untuk mendapatkan desain busana yang dekat dan sesuai dengan situasi dalam resepsi perkawinan, selain itu agar berbeda dengan busana-busana tarian percintaan lainnya yang berkembang pada dekade 1970-an (2013:wawancara). 
Selengkapnya busana dan asesoris yang dipakai Anjasmara, dapat dikelompokkan menjadi dua bagian untuk kepala dan badan. Bagian kepala memakai asesoris: gelung bangun tulak, bunga tiba ndhadha, cunduk mentul lima buah, cundhuk jungkat, giwang sepasang, kalung penanggalan (trètès), dan penetep. Busana untuk badan, terdiri atas: dodot tanggung, jarit samparan parang, slépé-janur, dan sampur. Asesorisnya berupa gelang sepasang. Adapun busana Damarwulan memakai jarit dodot prajuritan/sandhatan, sabuk, èpèk-timang, sampur, celana panjèn untuk badan, dan blangkon perbawan untuk kepala. Asesoris yang dikenakan kalung ulur, gelang sepasang, binggel sepasang, dan keris. Warna busana hijau dan corak kain sama, baik pakaian Damarwulan maupun Anjasmara adalah untuk mengekspresikan kesan segar dan cerah. Jenis-jenis asesoris yang dipakai berwarna kuning keemasan yang berkesan mewah dan agung.

\section{Musik}

Jenis-jenis gendhing sebagai musik pada Tari Endah, di antaranya: adegan 1 dan 2, Ayak-ayakan Mangu laras pélog pathet nem; adegan 3, Ladrang Énggar-énggar laras pélog pathet barang; dan adegan 4, Lancaran Makarya laras pélog pathet barang. Kedudukan musik dalam pertunjukan tari adalah sebagai pengiring atau medium bantu dalam mewujudkan sebuah pertunjukan tari. Sejalan dengan pernyataan itu, Humardani mengatakan bahwa dalam tari Jawa, musik karawitan sebagai iringan, banyak membantu memberikan kontribusi dan bahkan kerapkali menggantikan kedudukan kekuatan ekspresi tari (1991:10).

Dalam pertunjukan tari tradisional musik memegang peranan sangat penting, yakni sebagai: a) penunjuk isi, b) ilustrasi/ nglambari, c) membungkus/mungkus, dan d) menyatu/ nyawiji (Maryono, 2010:62). Berdasarkan data yang dapat dikumpulkan musik tari atau gendhing beksan pada Tari Endah lebih berfungsi sebagai: a) penunjuk isi, b) pembingkai, dan c) penyatu raga/ nyawiji. Musik pada Tari Endah yang berfungsi sebagai penunjuk isi dapat dicermati dari implikatur-implikatur pada masingmasing teks gérongan yang telah dijabarkan pada komponen verbal.

Musik pada Tari Endah yang berfungsi membungkus atau membingkai dimaknai sebagai bentuk musik yang ritme dan temponya membingkai beragam gerak yang disajikan penari terutama dikendalikan dengan pola-pola kendangan. Jenis-jenis gerak pada adegan gembira dibingkai dengan pola kendangan ciblonan yang iramanya tampak dinamis, sigrak, dan riang. Selain itu kendangan kébar juga terdapat pada adegan bahagia. Musik Tari Endah yang berfungsi nyawiji dimaksudkan adanya penyatuan rasa dari unsur-unsur gerak dari tari dengan unsur-unsur tempo, ritme, dan melodi dari musik sehingga membentuk pertunjukan tari yang memikat. Adegan penantian suasana gelisah, sedih, dan ragu-ragu didukung musik yang bernuansa sedih. Pada adegan gembira didukung musik yang bernuansa gembira. Begitu pula adegan bahagia didukung musik yang memiliki rasa gembira, riang, dan romantis.

\section{Analisis Komplementer Komponen Verbal dan Nonverbal}

Pemahaman makna secara kontekstual adalah sesuatu yang terjadi dalam interaksi subjek dan objek, sehingga ditemukan hal-hal baru setelah adanya aktivitas pengamatan secara mendalam sebagai pengayaan makna (Gadamer, dalam Sri Rustiyanti dkk, 2013: 46-47). Pandangan itu implementasinya dalam kesenian adalah 
bahwa seniman hanya menyediakan benda-benda pacu yang dapat bermakna bila dihayati, ditanggapi oleh penikmat. Kesadaran awal yang perlu diperhatikan adalah bahwa peristiwa kesenian itu tidak terlepas dari tiga hal pokok, yakni: seniman, karya seni (objek), dan penghayat (penikmat). Langkah awal yang harus dicermati dalam analisis Tari Endah adalah bentuk karya seni yang berkaitan dengan gagasan seniman, kemudian tanggapan penghayat dalam memberikan pemaknaan secara holistik.

Berdasarkan kajian komponen verbal pada Tari Endah tampak adanya koherensi antar aspek-aspek kebahasaan yang terakumulasi menjadi satu kesatuan saling berkaitan sehingga mencerminkan kesatuan makna yang dapat mengarahkan penghayat terhadap kandungan makna. Menurut Yule, implikatur adalah makna yang tersirat dalam percakapan (1986). Penemuan makna secara utuh dapat dibuktikan dengan mencermati dari implikatur teks-teks pada Tari Endah. Implikatur tembang gérongan Ayak-ayakan Mangu laras pélog pathet nem adalah bentuk ungkapan minta maaf dari Damarwulan terhadap Dewi Anjasmara istrinya dan sekaligus berjanji untuk mencintainya dengan setia. Implikatur tembang gérongan Ladrang Énggar-énggar laras pélog pathet barang adalah bentuk ungkapan cinta kasih, kesetiaan yang mendalam Damarwulan terhadap Dewi Anjasmara istrinya. Implikatur tembang gérongan Lancaran Makarya laras pélog pathet barang adalah penggambaran kebahagiaan Damarwulan dan istrinya Dewi Anjasmara dalam kebersamaannya membina rumah tangga. Merujuk dari implikatur-implikatur komponen verbal pada Tari Endah dapat ditemukan makna utamanya yang memberikan penggambaran perjalan-an kehidupan sepasang suami-istri yang romantis, harmonis, dan bahagia.

Dari uraian teks verbal gérongan Ayakayakan Mangu, gérongan Ladrang Énggar- énggar, dan gérongan Lancaran Makarya pada Tari Endah dapat diklasifikasikan menjadi beberapa jenis tindak tutur, yaitu: TT Direktif dan TT Ekspresif. Adapun TT Direktif mencapai: $64 \%$, dominasi jenis tindak tutur direktif pada komponen verbal tersebut, artinya terdapat pesan makna adanya sebuah perintah yang tidak langsung dari seniman penciptanya terhadap sepasang pengantin untuk mencontoh bentuk percintaan seperti yang digambarkan pada Tari Endah.

Komponen nonverbal pada tari merupakan media visual yang difungsikan sebagai sarana untuk mengekspresikan pesan makna supaya dapat ditangkap oleh penghayat. Bentuk komponen nonverbal pada Tari Endah, tentang tema menunjukkan percintaan Damarwulan dan Dewi Anjasmara. Aktualisasi percintaan digambarkan sepasang penari putra dan putri yang didominasi gerak-gerak representatif dari orang bercinta pada setiap adegan, seperti gerak: laku lémbéhan ukel karna, srisik nyandhet, lilingan ingsetan ulap-ulap tawing $k a-$ nan-kiri, laku telu, laku entrakan, srisik sambil berpegangan tangan, laku ogékan mandhé sampur sambil melingkar, srisik kembali saling mendekat, lilingan seblakan penthangan ingsetan, laku miring penthangan tawing kiri, laku miring berpegangan tangan, dan srisik penthangan sampur kiri dengan berpegangan tangan kanan. Bentuk rias dan busana terdapat kesamaan warna, pola-pola garis pada wajah, motif jarik, yang secara keseluruhan tampil gebyar, glamor, dan memikat menyerupai pengantin Jawa dikandung maksud adanya rasa menyatu. Karakteristik Damarwulan digambarkan sebagai seorang suami yang memiliki rasa tanggungjawab, romantis, dan setia terhadap istri. Adapun Dewi Anjasmara digambarkan sebagai figur seorang istri yang setia, romantis, dan berbakti terhadap suami. Gambaran karakteristik yang demikian bagi masyarakat Jawa merupakan pasang- 
an suami-istri yang ideal. Tampilan musik lebih banyak bernuansa gembira, riang dan romantis telah mendukung masing-masing adegan terasa menyatu dengan rasa gerak kedua peran Anjasmara dan Damarwulan sehingga memunculkan sebuah ekspresi percintaan yang romantis dan bahagia. Dengan demikian tampak bahwa akumulasi dari unsur-unsur pada komponen nonverbal: gerak, rias, busana, karakter, dan musik telah menggambarkan sebuah pertunjukan tari percintaan yang romantis dan bahagia yang secara artistik berkualitas dan bermakna.

Realita menunjukkan bahwa Tari Endah merupakan salah satu jenis tari percintaan yang hidup dan berkembang di masyarakat. Tari Endah biasa disajikan pada ritual perkawinan budaya Jawa. Tampilan Tari Endah pada ritual perkawinan menjadi salah satu suguhan yang sangat menarik, memikat, dan diminati bagi sepasang pengantin utamanya. Semakin tampak bahwa kehadiran Tari Endah dalam resepsi perkawinan memiliki makna bagi sepasang pengantin yaitu bentuk tari pasangan percintaan yang diharapkan dapat dicontoh dan diteladani untuk membina dan membentuk keluarga yang romantis dan bahagia.

\section{PENUTUP}

Berdasarkan analisis komponen verbal dan nonverbal pada Tari Endah didapat suatu simpulan bahwa Tari Endah merupakan salah satu bentuk tari pasangan percintaan yang diharapkan dapat dicontoh dan diteladani bagi sepasang pengantin dan masyarakat penonton pada umumnya. Bentuk keteladanan yang diharapkan adalah gambaran kehidupan sepasang suami istri yang romantis dan bahagia. Bagi sepasang pengantin pada khususnya, pemahaman kehadiran bentuk tari pasangan percintaan diharapkan dapat dicontoh dan diteladani, serta dapat berguna sebagai bekal untuk membina dan membentuk keluarganya yang romantis dan bahagia lahir dan batin.

Selain itu Tari Endah juga merupakan bentuk hiburan estetik yang sangat berguna bagi sepasang pengantin utamanya dan masyarakat penonton pada umumnya. Mengingat keindahan diciptakan untuk pemenuhan kebutuhan rohani dan jasmani dalam rangka aktivitas manusia, sekalipun karya itu dipetik dari jenis-jenis seni yang paling representatif. Seni merupakan ungkapan, bukan ungkapan benda atau gagasan semata, tetapi sebuah ungkapan pengalaman yang konkrit dengan kandungan nilai-nilai untuk dirinya. Seni adalah pengalaman dalam bentuk suatu medium sensa yang memikat dan tersusun secara harmoni yang diujudkan untuk dikomunikasikan dan direnungkan (Parker, 1980: 74-75). Nilainya terdapat pada penguasaan dan pemeliharaan kehidupan dalam imajinasi penghayat.

Berbagai komponen yang terdapat dalam pertunjukan tari tidak dapat dipahami secara terpisah-pisah dari posisi dan keterkaitannya dalam konteks keseluruhannya (Maryono, 2012: 70). Berawal dari beragam unsur-unsur yang terdapat pada masing-masing komponen pada Tari Endah telah diperlihatkan peran dan fungsinya, kemudian secara sistemik seluruh bagian tersebut saling mengait, menyatu, membentuk persenyawaan, sehingga hubungan komponen verbal dan nonverbal Tari Endah merupakan presentasi isi dan bentuk yang secara visual menggambarkan percintaan suami-istri yang romantis dan bahagia dan merupakan suatu karya tari yang berkualitas tinggi.

\section{Catatan Akhir}

${ }^{1}$ Tari Endah telah meraih juara I pada lomba tari tradisional tingkat Propinsi Jawa Tengah pada tanggal 9 Nopember 1992 (Pamardi, 2000:184). 


\section{Daftar Pustaka}

\section{Gadamer, Hans-Georg}

2004 Kebenaran dan Metode. Dalam Sri Rustiyanti dkk. Jurnal Panggung, Vol. 23 No.1 Maret 2013. STSI Bandung.

Kreidler, W. Charles

1998 Introducing English Semantics. London: Routledge.

Lamuddin Finoza

2005 Komposisi Bahasa Indonesia. Jakarta: Diksi Insan Mulia.

Leech, Geoffrey

1983 Principles of Pragmatics. New York: Longman.

1993 Prinsip-prinsip Pragmatik. Penerjemah: M.D.D Oka. Jakarta: Universitas Indonesia.

Levinson, Stephen C.

1983 Pragmatics. London: Cambridge University Press.

Maryono.

2010 Pragmatik Genre Tari Pasihan Gaya Surakarta. Surakarta: ISI Press.

2012 Analisa Tari. Penerbit: ISI Press Solo.

Parker, De Witt. H.

1980 Dasar-dasar Estetika. Penerjemah: SD. Humardani. Surakarta: Akademi Seni Karawitan Indonesia (ASKI).
Parker, Frank

1986 Linguistics for Non-linguistics. London: Taylor and Francis Ltd.

Soedarsono, R.M.

1978 Pengantar Pengetahuan dan Komposisi Tari. Yogyakarta: Akademi Seni Tari Indonesia (ASTI).

Silvester Pamardi

2000 'Peranan S. Maridi Dalam Perkembangan Tari Gaya Surakarta (Sebuah Biografi)'. Tesis. UGM Yogyakarta.

Sutarno Haryono

2010 Kajian Pragmatik Seni Pertunjukan Opera Jawa. Surakarta: ISI Press.

Yule, George

1998 Pragmatics. Singapore: National Institute of Education.

Nara Sumber:

1. Daryono. 55 tahun

Penari Alus, Dosen tari, sekarang merampungkan studi, Program Doktoral di ISI Surakarta.

2. Hartoyo. 57 tahun

Penari Alus Tari Endah dan perias pengantin, putra dari Empu tari S.Maridi dari Solo.

3. Ninik Sutranggi. 55 tahun

Penari putri Tari Endah dan perias pengantin, putra dari Empu tari S.Maridi dari Solo. 